Limnological Review (2011) 11, 4: 143-150

DOI 10.2478/v10194-011-0036-y

\title{
Lakes in the cascade model of storage and drainage reservoirs
}

\author{
Joanna Fac-Beneda \\ Department of Hydrology, University of Gdańsk, Bażyńskiego 4, 80-952 Gdańsk, Poland, e-mail: geojfb@univ.gda.pl
}

\begin{abstract}
The study area covers a compact, decentric hydrographic system called the Kashubian hydrographic system, which includes the drainage basins of the Słupia, Łupawa, Łeba, Reda, Wda, Wierzyca and Radunia. The Kashubian hydrographic system can be presented in the form of a cascade model of storage-drainage reservoirs - kord. One of the properties of a hydrographic system is its extent. Its horizontal extent is delimited by topographic watersheds, and its vertical extent is delimited at the bottom by the surface of the drainage base and in the roof by the land surface. Since reservoirs of the kord model are inscribed one into another, the upper border of all the reservoirs of the cascade is assumed to be the land surface, and the lower border of particular reservoirs of the cascade is a surface going through the level (elevation) of recipients receiving their waters. In the kord model on all its levels there are water reservoirs; however they differ in terms of origin, development, hydrological features and the role they play in the system. Depending on the type of recipient, drainage and storage can occur with various intensity. As follows from the hydrographic analysis the deepest lakes are situated in local and regional recipients, hence in these types of recipient, drainage and storage have greater intensity. On the other hand, in the transit recipient, transport is dominant.
\end{abstract}

Key words: young glacial areas, recipient, reservoir, kord model

\section{Introduction}

A hydrographic system involves the formation and then discharge of water excess through a definite and developed type of hydrographic network. A hydrographic system is a territorial system and can be presented as any other system in the form of a model, thanks to which it is possible to represent the functioning of the system. A hydrographic system has properties which have been determined by Drwal (1994) such as an absolute association of elements with a particular area, clearly determined boundaries, distinct structure, determinability of inferiority and superiority relationships, structural character of inferior units, mutual correlations of the functioning regime and structure of the system and discretizability of changes in time.

The Kashubian hydrographic system can be presented in the form of a cascade model of storagedrainage reservoirs - kord (Fac-Beneda 2011). The kord model is a more detailed and expanded version of the cascade model of storage reservoirs - mkor proposed by Drwal (Drwal and Hryniszak 2003). The kord model includes six reservoirs inscribed one into another: a reservoir of storage of hollows RZ, a reservoir of atmospheric inflow distribution $\mathbf{R D}$, a reservoir of constant outflow initiation ISO, a reservoir of autochthonous outflow OAU, a reservoir of allochthonous outflow OAL, and a reservoir of ultimate outflow identified with the whole catchment OO. Water excess from the RD reservoir is received by the initial recipient, excess from the ISO reservoir by the local recipient, from the OAU reservoir by the regional recipient, and from the OAL reservoir by the transit recipient.

In the shaping of water relationships of young glacial territorial systems an important role is played by lakes (Lange 1985; Drwal 1985; Nowiński 2009). The role they play in the functioning and organisation of potamic outflow is indicated by their position in the hydrographic system.

\section{Methods}

One of the properties of a hydrographic system is its extent. Its horizontal extent is delimited by topographic watersheds, and its vertical extent is delimited at the bottom by the surface of the drainage base and 
in the roof by the land surface (Fac-Beneda 2011). Since reservoirs of the kord model are inscribed one into another, the upper border of all the reservoirs of the cascade is assumed to be the land surface, and the lower border of particular reservoirs of the cascade is a surface going through the level (elevation) of recipients receiving their waters. For the OAL reservoir the base is the surface adjacent to the lowest point in the transit recipient. For the OAU reservoir the base is the surface adjacent to the lowest point of the regional recipient. For the ISO reservoir the base is the surface adjacent to the lowest point in the local recipient. These lowest points of recipients are determined in absolute values and approximately, i.e. not taking into account the depths of stream channels (in the cases of a lack of data for the ordinate of the channel bottom) or the thickness of bottom sediments of lakes (maximum depths of lakes are given without bottom sediments) (Table 1). The vertical extent of storagedrainage reservoirs is verified by the depth of lakes situated in the recipient. In the case of the distribution reservoir $\mathbf{R D}$ the base is not determined in absolute values. Since there is no component of base outflow here and only of subsurface outflow, it was assumed that the base of this reservoir will be situated maximally to $5 \mathrm{~m}$ below the land surface. This is the depth of the near-surface water bearing horizon determined by Piekarek-Jankowska (1979) in the central part of the Kashubian hydrographic system.

A separate issue is the determination of a recipient. In the Polish literature concerning young glacial areas, the definition of a recipient in the hydrographic system is not unambiguous. Drwal (1994), Drwal and
Borowiak (1996), Fac-Beneda et al. (2003) and FacBeneda $(2002,2007)$ used the term "recipient" but did not specify how the recipient should be distinguished, what border it has, what hydrographic objects it includes, what inlet and outlet points it has. The starting point was the adoption of the definition of recipient given by Drwal (1994) determining a recipient as one of the units of the elementary hydrographic structure. The criterion for the determination of the recipient was a relative height of $2.5 \mathrm{~m}$ (on 1:50 000 scale it is the contour interval). The analysis covered beds of $4^{\text {th }}$ order streams according to Drwal's hierarchisation (1982) and of higher orders, i.e. their channels with beds and bottoms of valleys, ice marginal streamways and channels. The border of the recipient was assumed to be the first contour line from the stream channel, the shore of a flow-through lake or from an erosional undercutting marked on a topographic map with a symbol (line joining ends of "teeth"). The criterion of height was adopted as it was earlier successfully used in the literature (Augustowski 1974; Łomniewski 1974). In places where valleys of streams of the $1^{\text {st }}, 2^{\text {nd }}$ and $3^{\text {rd }}$ order, and dry valleys reach the bed of the recipient, the line of the recipient's extent was drawn joining the places where the first contour line bent with a straight line parallel to the line of the stream. Since the hydrographic objects occurring within the recipient include short streams and melioration ditches, during demarcation of the recipient the catchments of these streams were included in its extent. The types of recipients and their distribution in $k s h$ were discussed in detail in the previous work by the author (Fac-Beneda 2011).

Table 1. Vertical extent of each reservoir of the cascade

\begin{tabular}{|c|c|c|c|c|c|c|}
\hline \multirow[b]{3}{*}{ Drainage basin } & \multicolumn{2}{|c|}{ RD, ISO, OAU, OAL, OO } & ISO & OAU & OAL & $\mathrm{OO}$ \\
\hline & maximum $[\mathrm{m}]$ & average $[\mathrm{m}]$ & \multicolumn{4}{|c|}{ minimum $[\mathrm{m}]$} \\
\hline & \multicolumn{2}{|c|}{ roof } & floor & floor & floor & floor \\
\hline Słupia & 267.3 & 116.5 & 7.5 & 23.4 & 2.4 & -5.6 \\
\hline Łupawa & 270.5 & 108.2 & 15.0 & 1.4 & -2.4 & - \\
\hline Łeba & 268.6 & 104.9 & 9.6 & 43.8 & 0.6 & -3.7 \\
\hline Reda & 237.8 & 112.3 & 23.4 & 23.8 & 19.1 & -1.0 \\
\hline Wda & 329.0 & 142.0 & 81.1 & 65.8 & 79.9 & 18.7 \\
\hline Wierzyca & 279.2 & 129.2 & 41.2 & 27.5 & 15.9 & 6.7 \\
\hline Radunia & 329.0 & 180.7 & 80.0 & 109.1 & 11.3 & 0.5 \\
\hline
\end{tabular}

RD - a reservoir of atmospheric inflow distribution, ISO - a reservoir of constant outflow initiation, OAU - a reservoir of autochthonous outflow, $\mathbf{O A L}$ - a reservoir of allochthonous outflow, $\mathbf{O O}$ - a reservoir of ultimate outflow identified with the whole catchment 


\section{Study area}

The study area covers a compact, decentric hydrographic system called the Kashubian hydrographic system, which includes the drainage basins of the Słupia, Łupawa, Łeba, Reda, Wda, Wierzyca and Radunia rivers (Fig. 1). From the Szymbarskie Hills, the centre of the system, water flows radially to the East (Radunia), North (Reda and Łeba), West (Łupawa and Słupia) and South (Wda and Wierzyca). "The axis of the system is a watershed of the $1^{\text {st }}$ order dividing the Vistula drainage basin and the drainage basins of the rivers of the coastal area" to quote Drwal (Drwal 1979, p.122). The drainage basin of the River Słupia was closed in Charnowo, the drainage basin of the Łupawa in Smołdzino, the drainage basin of the Łeba in Cecenowo, the drainage basin of the Reda in Wejherowo, the drainage basin of the Wda in Błędno, the drainage basin of the Wierzyca in Brody Pomorskie, and the drainage basin of the Radunia in Juszkowo. The thus delimited study area, in the shape of a polygon elongated from the North West to the South East, encompasses an area of about $7,600 \mathrm{~km}^{2}$. It is situated within the European Lowland (31) in the sub-provinces of the South Baltic Coastland (313) and South Baltic Lakeland (314) (Kondracki, 2002).

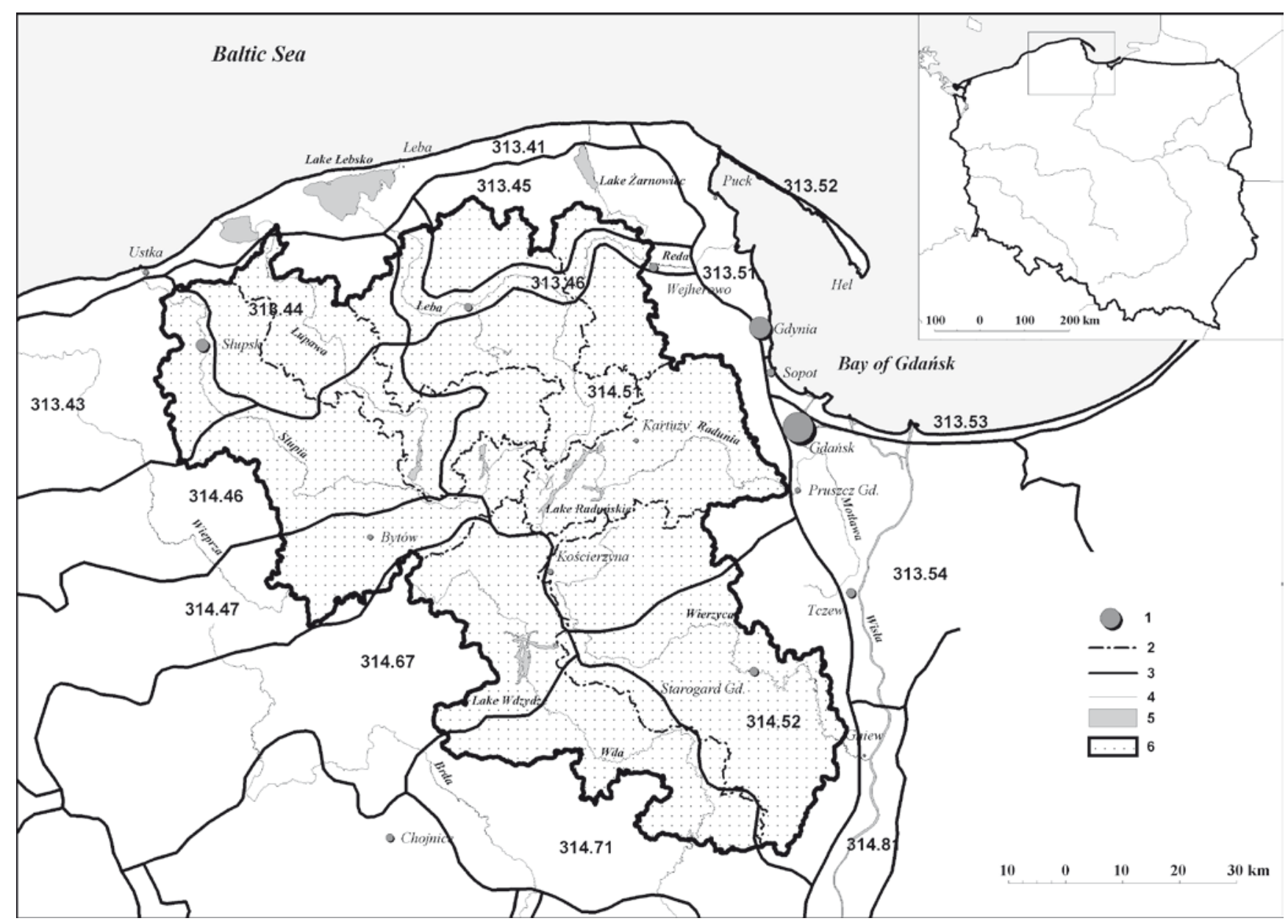

Fig. 1. Study area (according to Kondracki, 2002). Explanation: 1 - major towns, 2 - major drainage basins, 3 - mezoregion border (313.41 - Wybrzeże Słowińskie, 313.43 - Równina Słupska, 313.44 - Wysoczyzna Damnicka, 313.45 - Wysoczyzna Żarnowiecka, 313.46 - Pradolina Redy-Łeby, 313.51 - Pobrzeże Kaszubskie, 313.52 - Mierzeja Helska, 313.53 - Mierzeja Wiślana, 313.54 - Żuławy Wiślane, 314.46 - Wysoczyzna Polanowska, 314.47 - Pojezierze Bytowskie, 314.51 - Pojezierze Kaszubskie, 314.52 - Pojezierze Starogardzkie, 314.53 - Pojezierze Iławskie, 314.66 - Pojezierze Szczecinieckie, 314.67 - Równina Charzykowska, 314.71 - Bory Tucholskie, 314.81 Dolina Kwidzyńska), 4 - streams, 5 - lakes, 6 - ksh area 


\section{Results}

In the kord model on all its levels there are water reservoirs; however, they differ in terms of origin, development, hydrological features and the role they play in the system. In the kord model, the position of lakes can be presented in two ways - as the location of a lake in a storage-drainage reservoir and as the location of a lake in a recipient (Table 2). It should be noted that the lakes which occur in a recipient of a given type, occur also in the reservoir of a lower level in the cascade.

Lakes situated in the initial recipient also occur in the ISO reservoir; lakes situated in the local recipient occur in the OAU reservoir; lakes situated in the regional recipient occur in the OAL reservoir; and lakes situated in the transit recipient occur in the $\mathbf{O O}$ reservoir. Only on the level of reservoirs $\mathbf{R Z}$ and $\mathbf{R D}$ are there lakes which are not located in any recipient. They are mainly lakes and kettle ponds without outflow and, to a smaller degree, flow-through ones.
The extent of the $\mathbf{R Z}$ reservoir is identified with areas without outflow (Woźniak 2009). In the RZ reservoir there are lakes without outflow, and their main function is balancing water excess through vertical exchange. In the RD reservoir there are reservoirs of a small area and depth. There is a dominance of kettle ponds which are often subject to seasonal fluctuation of area. The number of kettle ponds per $100 \mathrm{~km}^{2}$ in the RD reservoir is from 64 in the Wda catchment to 169 in the Lupawa catchment. The mean density of occurrence of ponds in the RD reservoir is about 115 per $100 \mathrm{~km}^{2}$. The value is close to the one calculated for this level of the cascade in the head water part of $k s h$ by Drwal (1985). For the whole $k s h$ the mean density of ponds is 132 (from 219 per $100 \mathrm{~km}^{2}$ in the Wierzyca catchment to 71 per $100 \mathrm{~km}^{2}$ in the Wda catchment). The highest density of ponds was found in the differential catchment between the RD and ISO reservoirs (Table 3). This is connected with the highest proportion of areas without outflow on this level of the cascade.

Table 2. Number and area of larger natural reservoirs in the kord model

\begin{tabular}{|c|c|c|c|c|c|c|c|c|c|c|}
\hline \multirow{2}{*}{$\begin{array}{c}\text { Reservoir } \\
\text { Drainage basin }\end{array}$} & \multicolumn{2}{|c|}{ RD } & \multicolumn{2}{|c|}{ ISO } & \multicolumn{2}{|c|}{ OAU } & \multicolumn{2}{|c|}{ OAL } & \multicolumn{2}{|c|}{ OO } \\
\hline & number & area $^{1)}$ & number & area1) $^{1)}$ & number & area $^{1)}$ & number & area $^{1)}$ & number & area $^{1)}$ \\
\hline Słupia & 25 & 461 & 43 & 1826 & 24 & 348 & 9 & 183 & - & - \\
\hline Łupawa & 7 & 94 & 19 & 53 & 10 & 290 & 7 & 71 & - & - \\
\hline Łeba & 9 & 119 & 7 & 109 & 7 & 109 & 2 & 21 & - & - \\
\hline Reda & 10 & 152 & 5 & 189 & 2 & 85 & - & - & - & - \\
\hline Wda & 43 & 1004 & 50 & 1107 & 43 & 1390 & 18 & 1572 & 16 & 162 \\
\hline Wierzyca & 26 & 532 & 36 & 934 & 32 & 1178 & 5 & 41 & - & - \\
\hline Radunia & 21 & 778 & 14 & 256 & 15 & 1950 & 7 & 213 & - & - \\
\hline ksh & 139 & 3183 & 174 & 5375 & 133 & 5349 & 48 & 2101 & 16 & 162 \\
\hline
\end{tabular}

Explanation: see Table 1

1) area in hectares (Jańczak, 2007)

Table 3. Density of occurrence of kettle ponds on the levels of the cascade per $100 \mathrm{~km}^{2}$ (calculations in columns ISO-OO for differential area between cascade levels)

\begin{tabular}{|c|c|c|c|c|c|}
\hline Drainage basin Reservoir & RD & ISO & OAU & OAL & $\mathrm{OO}$ \\
\hline Słupia & 116 & 206 & 129 & 53 & 63 \\
\hline Łupawa & 169 & 108 & 122 & 65 & - \\
\hline Łeba & 106 & 406 & 96 & 115 & 77 \\
\hline Reda & 118 & 321 & 75 & 118 & 21 \\
\hline Wda & 64 & 221 & 55 & 50 & 28 \\
\hline Wierzyca & 145 & 981 & 213 & 146 & 51 \\
\hline Radunia & 121 & 817 & 104 & 58 & 77 \\
\hline ksh & 115 & 245 & 129 & 81 & 59 \\
\hline
\end{tabular}

Explanation: see Table 1 
In the next reservoir of the cascade - ISO - lakes occur both as flow-through and outflow reservoirs as well as without outflow. In this reservoir, lakes start to regulate the potamic outflow. In the OAU reservoir there are the largest and deepest lakes. A major part of the underground phase of water circulation in $k s h$ is again included in this reservoir into surface circulation by lake drainage. In ISO and OAU reservoirs both the number of occurring lakes and their total area is the highest (Table 1). In the OAL reservoir both the number and area of lakes are drastically reduced up to their disappearance in the $\mathbf{O O}$ reservoir. Only in the Wierzyca catchment in the $\mathbf{O O}$ are there 16 major natural reservoirs.
The transfer of water excess according to the kord model occurs in a hierarchical way from one reservoir to another by potamic outflow recorded in reservoirs and by sinking (Fig. 2). However, as it was shown by the research of the author (Fac-Beneda 2011) in the Kashubian hydrographic system, the transfer of excess occurs also bypassing the hierarchy. This process can occur either thanks to the existence of hydrogeological windows or through lakes. Lakes then perform a function which by analogy to the hydrogeological window can be called the function of a limnological window. Such a role of lakes was indicated in the papers by Jankowska (1985), Lange (1985), Okulanis (1985), or Nowicka and Lenartowicz (2004), and others.



Fig. 2. Location of major lakes of the $k s h$ in the kord model. Explanation: 1 - reservoir of the cascade, 2 - recipient, 3 - outflow, 4 - infiltration. RZ - a reservoir of kettle holes retention, RD - a reservoir of atmospheric inflow distribution, ISO - a reservoir of constant outflow initiation, OAU - a reservoir of autochthonous outflow, $\mathbf{O A L}$ - a reservoir of allochthonous outflow, $\mathbf{O O}$ - a reservoir of ultimate outflow identified with the whole catchment, $\mathbf{r}_{\text {ini }}-$ initial recipient, $\mathbf{r}_{\text {lok }}-$ local recipient, $\mathbf{r}_{\text {reg }}-$ regional recipient, $\mathbf{r}_{\text {tranz }}-$ transit recipient 
The location of lakes in recipients indicates what function is played by the recipient. It can be said that the recipient in whose area there are lakes receives water excess from particular reservoirs of the cascade, stores the excess permanently or/and temporarily and drains underground water horizons. The draining function of lakes was indicated in the papers by Pasławski (1975), Drwal (1985), Okulanis (1985), Borowiak (2000), Bajkiewicz-Grabowska (2007), or Borowiak and Barańczuk (2007), and others. If in the area of the recipient there is a stream of the $4^{\text {th }}$ or higher order, the recipient receives water excess from reservoirs of the cascade, temporarily stores it (channel retention), transports it and drains to the base of a particular reservoir of the cascade. If in the area of a recipient there is a waterlogged area, the recipient receives water excess from reservoirs of the cascade, stores it but it can also drain, though to a smaller degree than in the case of lakes. The conclusion is that all recipients play a drainage-storage function. Taking into consideration the fact that both lakes and waterlogged areas situated within a recipient have a flow-through character due to their location itself, recipients perform a transporting-draining-storing role. Depending on the type of recipient, drainage and stor- age can occur with various intensity. As follows from the table (Table 4) the deepest lakes are situated in local and regional recipients, hence in these types of recipient, drainage and storage have greater intensity. On the other hand, in the transit recipient, transport is dominant.

\section{Discussion}

The role of lakes in the Kashubian hydrographic system was analysed by, among others, Nowiński (2009) and Drwal (1985). Nowiński (2009), referring to the work by Bajkiewicz-Grabowska (2002), studied the upper part of the Radunia catchment as a hydrographic system, consisting of lake and river sections, whereas Drwal (1985) analysed lakes in territorial hydrographic systems. In the kord model only some lakes of the $k s h$ headwater area are situated on the same organisation level on which they are positioned by Drwal (1985) and Nowiński (2009). The analysis of the table (Table 4) indicates that only in two reservoirs, ISO and OAU, are there lakes which, according to all the researchers, occur on the same organisation level. In the case of the ISO reservoir, this is Lake Glinno, and in the case of the OAU reservoir this is Upper

Table 4. Location of lakes in the $k s h$ headwater area

\begin{tabular}{|c|c|c|c|c|c|}
\hline Reservoir & $\begin{array}{l}\text { Type of } \\
\text { receiver }\end{array}$ & $\begin{array}{l}\text { Lakes } \\
\text { in } \text { kord model }\end{array}$ & $\begin{array}{l}\text { Units of the regional } \\
\text { hydrographic structure }\end{array}$ & $\begin{array}{l}\text { Lakes in cascade } \\
\text { by Drwal (1985) }\end{array}$ & $\begin{array}{l}\text { Lakes in cascade } \\
\text { by Nowiński (2009) }\end{array}$ \\
\hline RD & & $\begin{array}{l}\text { Bukrzyno Duże, Bukrzyno } \\
\text { Małe, Lubowisko, Dąbrowskie, } \\
\text { Patulskie, Stężyckie, } \\
\text { Szewinko, Białe, Rekowo }\end{array}$ & initial catchments & ponds & Zamkowisko \\
\hline ISO & initial & Mausz, Glinno, Zamkowisko & local catchments & $\begin{array}{l}\text { Glinno, Boruckie, } \\
\text { Zamkowisko, Kniewo, } \\
\text { Żuromińskie, }\end{array}$ & $\begin{array}{l}\text { Lubowisko, Bukrzyno Małe, } \\
\text { Szewinko, Glinno, Boruckie }\end{array}$ \\
\hline OAU & local & $\begin{array}{l}\text { Gowilińskie, Raduńskie } \\
\text { Górne, Raduńskie Dolne, } \\
\text { Małe Brodno, Wielkie Brodno, } \\
\text { Ostrzyckie, Trzebno, Kłodno, } \\
\text { Boruckie }\end{array}$ & regional catchments ${ }^{1)}$ & $\begin{array}{l}\text { Raduńskie Górne, } \\
\text { Raduńskie Dolne, } \\
\text { Wdzydze, Gołuń, } \\
\text { Jelenie, Radolne, Mausz, } \\
\text { Gowidlińskie, Ostrzyckie }\end{array}$ & $\begin{array}{l}\text { Stężyckie, Kłodno, } \\
\text { Białe, Raduńskie Górne, } \\
\text { Raduńskie Dolne, } \\
\text { Dąbrowskie, Patulskie, } \\
\text { Bukrzyno Duże, Rekowo, } \\
\text { Małe Brodno, Wielkie Brodno }\end{array}$ \\
\hline OAL & regional & $\begin{array}{l}\text { Wdzydze, Gołuń, Jelenie, } \\
\text { Radolne }\end{array}$ & & $\begin{array}{l}\text { Res. Łapino, Res. } \\
\text { Bielkówko, Straszyńskie }\end{array}$ & Trzebno, Ostrzyckie \\
\hline O० & transit & $\begin{array}{l}\text { Res. Łapino, Res. Bielkówko, } \\
\text { Straszyńskie }\end{array}$ & & - & - \\
\hline
\end{tabular}

Explanation: RD - a reservoir of atmospheric inflow distribution, ISO - a reservoir of constant outflow initiation, OAU - a reservoir of autochthonous outflow, $\mathbf{O A L}$ - a reservoir of allochthonous outflow, $\mathbf{O O}$-a reservoir of ultimate outflow identified with the whole catchment

1) regional catchments according to Drwal (1985) and Nowiński (2009) 
Lake Raduńskie and Lower Lake Raduńskie. It should, however, be noted that Nowiński considered only the system of the upper Radunia.

\section{Conclusion}

A clear-cut positioning of lakes in the hydrographic system in the light of the kord cascade model of storage-drainage reservoirs enables the determination of the manner and ways of water excess discharge and shows which function is played by lakes in the functioning and organisation of potamic outflow in the system. Lakes positioned in recipients (according to the model) by receiving water excess perform both a storing as well as transporting and draining function. Since in young glacial areas lakes constitute the dominant feature of the hydrosphere, consequently it is possible to determine the role of water reservoirs in the exchange of energy and matter and in the shaping of water relationships of these areas.

\section{References}

Augustowski B., 1974, Rzeźba terenu (Land relief), [in:] Moniak J. (ed.), Studium geograficzno-przyrodnicze i ekonomiczne województwa gdańskiego (Geography, natural and economic study of Gdańsk Province), GTN, Gdańsk: 37-90 (in Polish, English summary).

Bajkiewicz-Grabowska E., 2002, Obieg materii w systemach rzeczno-jeziornych (Circulation of matter in fluvial-lacustrine systems), Wyd. UW, Warszawa, p. 274 (in Polish, English summary).

Bajkiewicz-Grabowska E., 2007, Jeziorne ogniwa w sieci hydrograficznej obszarów młodoglacjalnych i ich rola w kształtowaniu odpływu rzeki pojeziernej (Lacustrine cells in the hydrographic network of young glacial areas and their role in formation of the outflow of the youngglacial/lakeland river), [in:] Michalczyk Z. (ed.), Obieg wody $\mathrm{w}$ środowisku naturalnym i przekształconym (Water circulation in natural and transformed environment), Badania hydrograficzne w poznaniu środowiska 8: 39-46 (in Polish).

Borowiak D., 2000, Reżimy wodne i funkcje hydrologiczne jezior Niżu Polskiego (Water regimes and hydrological functions of lakes of Polish Lowland), Bad. Limnol. 2, Wyd. KLUG, Gdańsk, p.164 (in Polish, English summary).

Borowiak D., Barańczuk J., 2007, Kształtowanie się odpływu ze zlewni jeziornej (Formation of runoff from lake catchment), [in:] Michalczyk Z. (ed.), Obieg wody w środowisku naturalnym i przekształconym (Water circulation in natural and transformed environment), Badania hydrograficzne w poznaniu środowiska 8: 97-107 (in Polish).
Drwal J., 1979, Charakterystyka hydrograficzna (Hydrographic characteristics), [in:] Augustowski B. (ed.), Pojezierze Kaszubskie (Kashubian Lake District), GTN, Gdańsk: 121-138 (in Polish, English summary).

Drwal J., 1985, Jeziora w egzoreicznych systemach pojezierzy młodoglacjalnych (Lakes in exoreic systems of young-glacial lakelands), Zesz. Nauk. Wydz. BiNoZ UG, Geografia 14: 7-15 (in Polish, English summary).

Drwal J., 1994, Geograficzna interpretacja systemów hydrograficznych w terenach młodej plejstoceńskiej akumulacji polodowcowej (Geographical interpretation of hydrographic systems in areas of young Pleistocene glacial accumulation) [Manuscript], Uniwersytet Gdański, Gdańsk, p. 156 (in Polish).

Drwal J., Borowiak M., 1996, Hydrograficzne uwarunkowania odpływu potamicznego (Hydrographic conditions of potamic outflow), [in:] Szukalski J. (ed.), Pojezierze Starogardzkie. Część 1, Środowisko przyrodnicze (Starogardzkie Lakeland. Part 1, The natural environment), GTNWyd. Gdańskie, Gdańsk: 107-121 (in Polish).

Drwal J., Hryniszak E., 2003, Obieg wody w wybranych geoekosystemach Pomorza Zachodniego (Water circulation in selected geoecosystems of the West Pomerania), [in:] Kostrzewski A., Szpikowski J. (eds), Funkcjonowanie geoekosystemów zlewni rzecznych (The functioning of geosystems of river catchments), Bogucki Wyd. Nauk., Poznań: 127-137 (in Polish).

Fac-Beneda J., Jereczek K., Magierska S., 2003, Struktura hydrograficzna zlewni Łupawy po profil Smołdzino (Hydrographic structure of the Eupawa catchment for the Smołdzino gauge station), [in:] Kostrzewski A., Szpikowski J. (eds), Funkcjonowanie geoekosystemów zlewni rzecznych (The functioning of geosystems of river catchments), Bogucki Wyd. Nauk., Poznań: 139-147 (in Polish).

Fac-Beneda J., 2002, Elementarna struktura hydrograficzna wschodniej części delty Wisły (Elementary hydrographic structure of the eastern Vistula delta), [in:] Drwal J. (ed.) Wody delty Wisły, część wschodnia (Waters of the Vistula delta, eastern part), GTN, Gdańsk: 83-94 (in Polish, English summary).

Fac-Beneda J., 2007, Formowanie się i organizacja odpływu w systemie Słupi, Łupawy i Łeby (The formation and organisation of outflow in the system of the Słupia, Eupawa and Łeba), [in:] Michalczyk Z. (ed.), Obieg wody w środowisku naturalnym i przekształconym (Water circulation in natural and transformed environment), Badania hydrograficzne w poznaniu środowiska 8: 203-210 (in Polish).

Fac-Beneda J., 2011, Młodoglacjalny system hydrograficzny (Young-glacial hydrographic system), Wyd. UG, Gdańsk, p. 213 (in Polish, English summary).

Jankowska H., 1985, Znaczenie jezior w kształtowaniu odpływu podziemnego w dorzeczu górnej Raduni (The importance of the lakes in underground outflow forming in the upper Radunia drainage basin), Zesz. Nauk. Wydz. BGiO UG, Geografia 14: 57-67 (in Polish, English summary). 
Jańczak J. (ed.), 2007, Atlas jezior Polski, t. 2 (Atlas of Polish Lakes, vol. 2), Bogucki Wyd. Nauk., Poznań, p. 256 (in Polish).

Kondracki J., 2002, Geografia Fizyczna Polski (Physical Geography of Poland), PWN, Warszawa, p. 450 (in Polish).

Lange W., 1985, Jeziora jako terytorialne systemy przyrodnicze (Lakes as natural territorial systems), Zesz. Nauk. BGiO UG, Geografia 14: 17-30 (in Polish, English summary).

Łomniewski K., 1974, Stosunki hydrograficzne (Hydrographic relationships), [in:] Moniak J. (ed.), Studium geograficzno-przyrodnicze i ekonomiczne województwa gdańskiego (Geography, natural and economic study of Gdańsk Province), GTN, Gdańsk:145-191 (in Polish, English summary).

Nowicka B., Lenartowicz M., 2004, Variability in the process of lake feeding by groundwater (case study of small basin in south Pomeranian Lake District), [in:] Progress In Surface And Subsurface Water Studies At Plot And Small Basin Scale, Proc. of the $10^{\text {th }}$ Conference of the Euromediterranean Network of Experimental and Representative Basins (ERB), Turin, Italy, 13 -17 October 2004: $15-21$.
Nowiński K., 2009, Rola jezior w transformacji jakości wód systemu Raduni (The role of lakes in the transformation of water quality in the Radunia system) [Dissertation], Uniwersytet Gdański, Gdańsk, p. 236 (in Polish).

Okulanis E., 1985, Rola jezior w kształtowaniu stosunków hydrologicznych w wybranych zlewniach Pojezierza Kaszubskiego (Role of lakes in the formation of hydrological relationships in selected catchments of the Kashubian Lakeland), Zesz. Nauk. Wydz. BGiO UG, Geografia 14: 31-44 (in Polish, English summary).

Pasławski Z., 1975, Typologia hydrologiczna jezior Pojezierza Wielkopolskiego (Hydrological typology of lakes of the Wielkopolskie Lakeland), Prz. Geofiz. 20: 271-280 (in Polish, English summary).

Woźniak E., 2009, Rola obszaru endoreicznego Linia w bilansowaniu opadu atmosferycznego (The role of the Linia endorheic area in balancing precipitation) [Dissertation], Uniwersytet Gdański, Gdańsk, p. 149 (in Polish). 